\title{
Перспективы и проблемы, связанные с разработкой и добычей сланцевого газа
}

\author{
Д.П. Гериш ${ }^{a}$, О.Е. Кочнева \\ ${ }^{a}$ Пермский государственный национальный исследовательский универси- \\ тет, 614990, Пермь, ул. Букирева, 15. E-mail: denger 47@gmail.com \\ ${ }^{\mathrm{b}}$ Пермский национальный исследовательский политехнический универси- \\ тет, 614990, Пермь, Комсомольский пр., 29 \\ E-mail: olgakochneva777@yandex.ru
}

\begin{abstract}
Описываются основные аспекты добычи сланцевого газа, его происхождение и свойства, анализируются особенности сланцевого газа, отношение к данному виду топлива в Российской Федерации. Отдельно выделены общие проблемы, которые возникают при добыче сланцевого газа. Показаны текущие и прогнозные показатели добычи в США.

Ключевые слова: сланцевый газ; проблемы; сланцыь; альтернатива; перспективы; добыча; трудности.
\end{abstract}

В настоящее время возникла необходимость в разработке новых источников энергетических ресурсов и их технологии добычи. В последнее время всеми энергозависимыми странами активно развиваются технологии-заменители по производству возобновляемого топлива. Единственным энергоисточником, имеющим на сегодняшний день исключительные качества товара-заменителя, является сланцевый газ.

Сланцевый газ представляет собой разновидность природного газа, хранящегося в виде небольших газовых образований в коллекторах, в сланцевых толщах осадочных пород Земли. Он образуется в результате анаэробных химических процессов. Сланцевый газ состоит преимущественно из метана, но в его состав входят и другие газы с разным процентным содержанием. Его примерному составу отвечает следующее содержание компонентов, \%: $\mathrm{H}_{2}$ 25-40; $\mathrm{CH}_{4}$ 14-17; $\mathrm{CO} 10-20 ; \mathrm{CO}_{2}$ 10-20; $\mathrm{C}_{2} \mathrm{H}_{6}$ и другие углеводы 4-5; $\mathrm{N}_{2} 22-25 \%$; $\mathrm{O}_{2}$ не более 1. Как и любое вещество, сланцевый газ обладает рядом свойств.
Плотность газа колеблется от 0,7 до 0,9 кг/ $\mathrm{M}^{3}$. Температура газокислородного пламени составляет $2000^{\circ} \mathrm{C}$. Низшая теплота

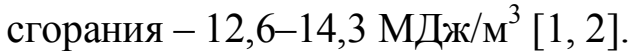

Запасы сланцевого газа сосредоточены в глинистых сланцах, это те же глины, измененные на большой глубине под действием высоких давлений и температур. Порода теряет пластичность и становится хрупкой и трещиноватой, обладает очень низкой проницаемостью. Сланцы, содержащие газ, - это особые горючие сланцы [7].

В отличие от обычных глинистых сланцев горючие сланцы содержат органическое вещество - кероген, похожий на уголь. Содержание керогена является качественным показателем газовой эффективности сланца. К наиболее термически зрелым сланцам относят месторождения «сухого газа» с керогеном. При оценке месторождений нужно понимать, что объем доступного газа в сланцевом слое прямо пропорционален мощности толщи. Очевидно, что наиболее выгодными являются мощные пласты катагенетически зрелых сланцев. Запасы отдельных газо- 
вых коллекторов невелики, но огромны в совокупности и требуют специальных технологий добычи. Сланцевые залежи встречаются на всех континентах, поэтому практически любая энергозависимая страна может себя обеспечить необходимым энергоресурсом [3, 4].

Первая коммерческая газовая скважина в сланцевых пластах была пробурена в США в 1821 г. Вильямом Хартом, который считается в США «отцом природного газа». Первое месторождение сланцевого газа разрабатывалось в штате Техас и использовалось как полигон для испытаний технологии. Первые экспериментальные разработки в области газодобычи из сланца начали проводиться в США компанией Mitchell Energy\&Development во главе с Д. Митчеллом с 1980 г. [6].

Масштабное промышленное производство сланцевого газа было начато в начале 2000-х на месторождении Barnett Shale. Высокая себестоимость газа, добытого газа из сланца, первоначально была связана с тем, что для поисков бурились многочисленные вертикальные скважины, проводился гидроразрыв пласта и откачивался газ. Сочетание вертикального и горизонтального бурения начали использовать только с 2002 г. Применение горизонтального бурения значительно сократило себестоимость добытого газа [5].

В настоящее время сланцевый газ добывается практически во всех развитых и развивающихся странах и экспортируется в другие страны или используется в собственной промышленности.

Общий объем сланцевого газа, добытого в течение прошедших 10 лет, эксперты оценивали в 456 трлн м³. По данным годового отчета Energy Information Administration (EIA), объем запасов сланцевого газа США на 2011 г. составляет 72 трлн м ${ }^{3}$, из них технически извлекаемые запасы - 24 трлн м³ ${ }^{3}$ В то же время, по данным Международного энергетического агентства (МЭА), на основании исследований нетрадиционные запасы газа составляют всего 4\% доказанных запасов природного газа [8].
В России, по данным отчета компании OAO «Газпром», нетрадиционные запасы газа составляют 83,7 млрд м ${ }^{3}$. В осадочных породах на Русской плите широко представлены сланцы разной мощности и зрелости, которые могут быть перспективными для разработки. Стоит выделить на Восточно-Европейской платформе Балтийский щит и Польско-Литовскую впадину, находящуюся на территории Польши и Западной Украины, а также Днепровско-Донецкую впадину на территории Украины, обладающие запасами зрелого сланца. На российской части Балтийского щита в Южно-Скандинавской области имеются незрелые сланцы возрастом 2,8 млрд лет, более зрелые сланцы расположены в Центрально-Кольском блоке [3].

В январе 2011 г., заместителем директора Института энергетической стратегии Российской Федерации А. Громовым были названы следующие цифры добычи сланцевого газа в мире: к 2018 г. объем добычи составит 180 млрд м ${ }^{3}$ в год, а к 2030 г. добыча сланцевого газа в США будет не более 150 млрд м ${ }^{3}$ в год.

Сланцевый газ является разновидностью природного газа, образовавшегося в недрах земли. Современная технология добычи сланцевого газа подразумевает бурение одной вертикальной скважины и нескольких горизонтальных скважин длиной до двух - трех километров. В пробуренные скважины закачивается смесь воды, песка и химикатов, в результате гидроудара разрушаются стенки газовых коллекторов, и весь доступный газ откачивается на поверхность. При бурении горизонтальной скважины важно соблюдать правила бурения, к ним относится, например, выбор правильного угла бурения, соответствующего углу наклона сланцевого пласта. Скважина должна пролегать строго в пределах сланцевого пласта на достаточном расстоянии от его границ, в противном случае метан мигрирует через трещины и другие отверстия в верхний слой осадочных пород. Газовые коллекторы в сланцевом пласте также имеют свои отличия и сконцентрированы в порах 
сланца аналогично хранению газа в плотном песке, в виде скоплений возле источника органических веществ подобно метану в угольных пластах и в виде скоплений в природных переломах.

Технология гидроразрыва пласта была разработана в 1953 г. академиком С.А. Христиановичем совместно с Ю.П. Желтовым в Институте нефти АН СССР. Для разработки эффективной технологии горизонтального бурения с гидроразрывом пласта понадобилось около 20 лет экспериментов [4].

Начало добычи сланцевого газа - caмое важное событие в энергобизнесе за последние 50 лет. Его результатом стало перепроизводство газа и обвал цен в Северной Америке. В 2009 г. США обогнали Россию по объемам добычи природного газа. По состоянию на 2012 г. газ в США стоит существенно дешевле, чем в России, которая обладает крупнейшими в мире разведанными запасами газа. Дальнейшее падение цен ожидается после строительства мощностей для экспорта сжиженного газа за пределы Северной Америки.

В настоящее время российские компании осознали, что сланцевая революция это серьезно, а распространение по миру технологий добычи и танкеров со сжиженным газом неизбежно. Минэнерго продолжает убеждать правительство в отсутствии сланцевой угрозы, одновременно утверждая, что сланцы добывать хоть и сложно, невыгодно и неэкологично, но надо. Во-первых, из-за того, что стране неплохо было бы освоить американские революционные технологии, т.е. горизонтальное бурение вместе с гидроразрывом пластов. Во-вторых, сланцевый газ может стать локальным источником энергии в тех регионах, которые не подключены к магистральным газопроводам (северные районы, Дальний Восток, Сибирь) [5].

Пока геологическое изучение горючих сланцев России не проводилось. Нет не только данных о том, сколько может храниться сланцевого газа в недрах России, но даже примерных областей его залежей. Минэнерго предлагает начать разработку сланцев уже с 2014 г.

Технология добычи сланцевого газа, как любая промышленная технология, подразумевает позитивные и негативные стороны. Существовали мнения, что разработку сланцевых месторождений с использованием глубинного гидроразрыва пласта в горизонтальных скважинах можно проводить в густозаселенных районах (единственной проблемой будет использование тяжелого транспорта), что значительные сланцевые месторождения газа находятся в непосредственной близости от конечных потребителей, что добыча сланцевого газа происходит без потери парниковых газов. Однако после 10 лет эксплуатации скважин были выделены следующие проблемы:

1. Технология гидроразрыва пласта требует крупных запасов воды вблизи месторождений, для одного гидроразрыва используется смесь воды (7500 т), песка и химикатов. В результате вблизи месторождений скапливаются значительные объемы отработанной загрязненной воды, которая не утилизируется добытчиками с соблюдением экологических норм [4].

2. Как показывает опыт разработки Barnett Shale, сланцевые скважины имеют гораздо меньший срок эксплуатации, чем скважины обычного природного газа [2].

3. Формулы химического коктейля для гидроразрыва в компаниях, добывающих сланцевый газ, являются конфиденциальными. По отчетам экологов добыча сланцевого газа приводит к значительному загрязнению грунтовых вод толуолом, бензолом, диметилбензолом, этилбензолом, мышьяком и др. Некоторые компании используют соляно-кислотный раствор, загущенный с помощью полимера, для одной операции гидроразрыва используется 80-300 т химикатов [4].

4. При добыче сланцевого газа имеются значительные потери метана, что приводит к усилению парникового эффекта.

5. Добыча сланцевого газа рентабельна только при наличии спроса и высоких цен на газ [2].

Добыча сланцевого газа в XXI в. еще 
только набирает свои обороты, но, несмотря на короткий производственный цикл, пагубно отражается на экологии районов. Этот вид топлива активно заменяет традиционные энергетические источники, такие как природный газ, уголь и даже дизельное топливо. Но технология добычи сланцевого газа требует более безопасного и экологически чистого метода разработки, т.к. оказывается огромное воздействие на биосферу. Для того чтобы начать добычу топлива, требуются большие затраты, связанные как с природными ресурсами (вода, песок), так и химическими веществами, которые закачиваются в недра Земли и «отравляют» местность вокруг района добычи.

Исследования подчеркивают необходимость дальнейшего усовершенствования технологии добычи сланцевого газа с целью контроля выбросов метана, загрязнения почвы и грунтовых вод, учитывая высокий уровень неопределенности в оценочных цифрах. К сожалению, на фоне картины истощения традиционных запасов газа сланцевый газ не сможет стать в ближайшее время достойной альтернативой, т. к. не соответствует современным экологическим требованиям к энергоресурсу. Перспективы крупной добычи сланцевого газа в настоящее время имеются только в слабозаселенных районах и в странах, которые согласны на снижение экологической безопасности. Иногда стоит задуматься над тем, что важнее: окру- жающая нас природа или экономическое развитие страны.

\section{Библиографический список}

1. Байков Н.М., Байкова Е.Н. Перспективы разработки сланцевой нефти // Нефтяное хозяйство. 2013. №5. С. 120-123.

2. Борисов Д. Финэнерго. 2012. URL: www.pronedra.ru/gas/2011/12/23/slancevyjgaz .

3. Жаркова А.М. Оценка потенциала сланцевых углеводородов России // Минеральные ресурсы России. Экономика и управление. 2011. №3. С. 16-21.

4. Карасёва Т.В., Назаров А.С. Связанный газ - новый объект исследования нефтегазовой геологии // Вестник Пермского университета. Геология. 2010. Вып.1 (9). С. 8 14.

5. Кочнева О.Е., Гайнитдинов А.А. О конкурентоспособности нетрадиционных источников углеводородов на мировых рынках // Журнал магистров / Перм. нац. исслед. политехн. ун-т. Пермь, 2014. С. 96103.

6. Муслимов Р.Х., Плотникова И.Н. О сланцевой нефти Республики Татарстан // Нефтяное хозяйство. 2014. №1. С. 12-15.

7. Муслимов Р.Х. Проблемы инновационного проектирования разработки особенно сложных месторождений с трудноизвлекаемыми запасами нефти // Нефтяное хозяйство. 2012. №10. С.92-97.

8. Svargaman. Сланцевый газ подробно. 2012. URL: www.voprosik.net/slancevyjgaz-podrobno/ .

\title{
Perspectives and Problems related to the Shale Gas Production
}

\author{
D.P. Gerish ${ }^{\text {a }}$, O.E. Kochneva ${ }^{\text {b }}$ \\ ${ }^{a}$ Perm State University, 15 Bukireva Str., 614990 Perm, Russia E-mail: denger \\ 47@gmail.com \\ ${ }^{\mathrm{b}}$ Perm National Research Polytechnic University., 29 Komsomolskiy Pr., \\ 614990 Perm, Russia E-mail: olgakochneva777@yandex.ru
}

This article describes the main aspects of shale gas production, its origin and properties. 
The particular issues related to the shale gas production, as well as the public and official attitude to the perspectives of its usage in Russian Federation are analyzed. The general problems of the shale gas exploration and production in the Russian Federation are discussed. The current and prognostic rates of shale gas production in USA are shown.

Keywords: shale gas; problems; shale; alternative perspectives; mining; difficulties.

\section{References}

1. Baykov N.M., Baykova E.N. 2013. Perspektivy razrabotki slantsevoy nefti [Perspectives of shale oil production]. Neftyanoe khozyaystvo. 5: 120-123.

2. Borisov D. 2012. Finenergo. URL: www. pronedra.ru/gas/2011/12/23/slancevyj-gaz .

3. Zharkova A.M. 2011. Otsenka potentsiala slantsevykh uglevodorodov Rossii [Assessment of the shale hydrocarbons potential in Russia]. Mineralnye resursy Rossii. Ekonomika i upravlenie. 3: 16-21.

4. Karasyova T.V., Nazarov A.S. 2010. Svyazannyy gaz - novyy obyekt issledovaniya neftegazovoy geologii [Fixed gas as a new subject of oil and gas geology investigation]. Vestnik Permskogo universiteta. Geologiya. 1 (9): 8-14.

5. Kochneva O.E., Gaynitdinov A.A. 2014. O konkurentnosposobnosti netraditsionnykh is- tochnikov uglevodorodov na mirovykh rynkakh [About a competitive ability of nontraditional sources of hydrocarbons in the world market]. In Zhurnal magistrov. Perm, Perm nats. issl. polytech. univ., pp. 96-103.

6. Muslimov R.Kh., Plotnikova I.N. 2014. O slantsevoy nefti Respubliki Tatarstan [About shale oil of the Tatarstan Republic]. Neftyanoe khozyaystvo. 1: 12-15.

7. Muslimov R.Kh. 2012. Problemy innovatsionnogo proektirovaniya razrabotki osobenno slozhnykh mestorozhdeniy s trudnoizvlekaemymi zapasami nefti [Problems of innovation design of development of very complicated stranded oil deposits]. Neftyanoe khozyaystvo. 10: 92-97.

8. Svargaman. 2012. Slantsevyy gaz podrobno [Shale gas in detail]. URL: www. voprosik.net/slancevyj-gaz-podrobno/ . 